\title{
Subtotal Amputation of The Ear
}

\author{
Mirjana Stracenski Perge* \\ General Hospital of Sremska Mitrovica, Urosa Stojsica 4622000 Sremska Mitrovica, Serbia
}

Submission: November 08, 2018; Published: November 20, 2018

*Corresponding author: Mirjana Stracenski Perge, General Hospital of Sremska Mitrovica,Urosa Stojsica 4622000 Sremska Mitrovic,a Serbia

\begin{abstract}
In this case report, the left ear of a 33 years old man was subtotaly amputated in fight with the sharp object- small parts of the glass bottle. Amputation resulted in tissue avulsion - parts of the ear (skin and cartilage)were groggy with irregular wound borders and located at the inferior part of the ear. Due to other wounds , the primariae suturae without microsurgery was the best treatment option .Result was ssatisfying appearance of the auricle which is sweepingly exchangeable and preserved lumen of the external auditory canal which resulted in normal hearing.
\end{abstract}

\section{Introduction}

Injury of the external ear are common due to its prominence. Injury of the auricle are most often caused by mechanical force( sharp or blunt) .The subtotal ear amputation is the avulsion of almost whole tissue of the auricle. The options for the reconstruction depends on the location, extend of the injury and blood vesel size. Misrosurgical ear replantation is the best choise for the reconstruction in the case with amputated pedicle, but in some reasons such as an associated trauma besides the main injury and small vessel size of the amputated part, this kind of treatmen is not possible. In general, in subtotal amputation,survival depends on vascularization within the pedicle. In my case report- my intention was to achieve appropriate cosmetic result of the auricle in order to allow future ear reconstruction in the case of operative failure.

\section{Case Report}

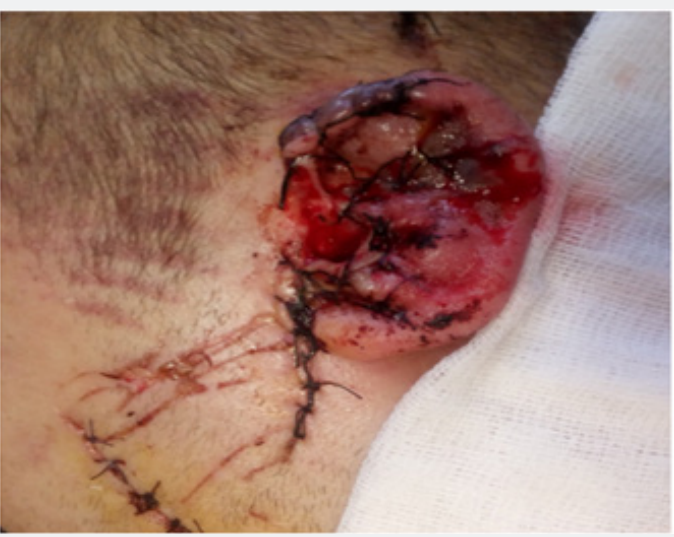

Figure 1: Second day after surgery.

Here I want to present the case of 33 years old man. He got a subtotal amputation of the left ear in fight. Injury was created with the sharp object- small parts of the botlle glass. Amputation resulted in tissue avulsion with irregular wound borders. Parts of the ear were groggy and located at the inferior part of the ear,near lobule of the auricle. The patient had associated injurystamb wound on his back with knife and stamb wound of his finger on one hand with knife. On physical examination upon presentation, patient was hemodynamically stable but in acute stress. He was in an alcoholic state[1]. CT of the endocraniumwas normal finding, Laboratory findings were normal. He was also a smoker and he had an additional disease- asthma. The aim of therapy was first stop the bleading, than patent external auditory canal and reconstruction of the auricle. We beginning work(with his ear)after $1 \mathrm{~h}$ - when surgeon and orthoped finished their job . Rconstruction of all the presented parts of the skin and cartilage was done with primariae sutures- surgical thread Assu Cryl-lactin 5.0) without microsurgical methods in local anesthesia (Figure 1). Postoperatively we administrated Antibiotic - Ciprofloxacine- amp. a 100mg.- $1 \mathrm{x} 4 \mathrm{amp} / 12 \mathrm{~h}$ i.v. for one weak. Iodine gauze- was placed in the external auditory canal in order to prevent the stenosis [2]. Rewinding was done at the beginning every day, first seven days and later every second day with no tight dressing- in order to prevent pressure necrosis wich represent the most disastour complication. Lubrication with Enbecin ointment(Bacitracin,Neomicin) was done generously in order to prevent desiccation,desquamation and deepitelization. Venous congestion was seen second day after surgery - (Figure 1) and intermittent bleading was performed by mechanical drainage to improve circulation for four days. Patient was in hospital for 10 days . After 15.days (Figure 2) it could be seen a partial skin necrosis on the helical rim( upper arrow) and haematoma on the inferior part of the auricle ( lower arrow). Five montht s after injury (Figure 3) the auricle is sweepingly exchangeable, external auditory canal is a preserved 


\section{Global Journal of Otolaryngology}

lumen and otomycroscopic finding is neat. All the time patient states that the hearing is good. In comparation with his right normal ear (Figure 4) left reconstructed ear is $1,5 \mathrm{~cm}$ shorter. On the same control finding after 5 months we performed tonal audiometry (Figure 5). The result was Intipient Sensorineural hearing loss on the bothe side but patient was warder in the prison and carrying weapons.
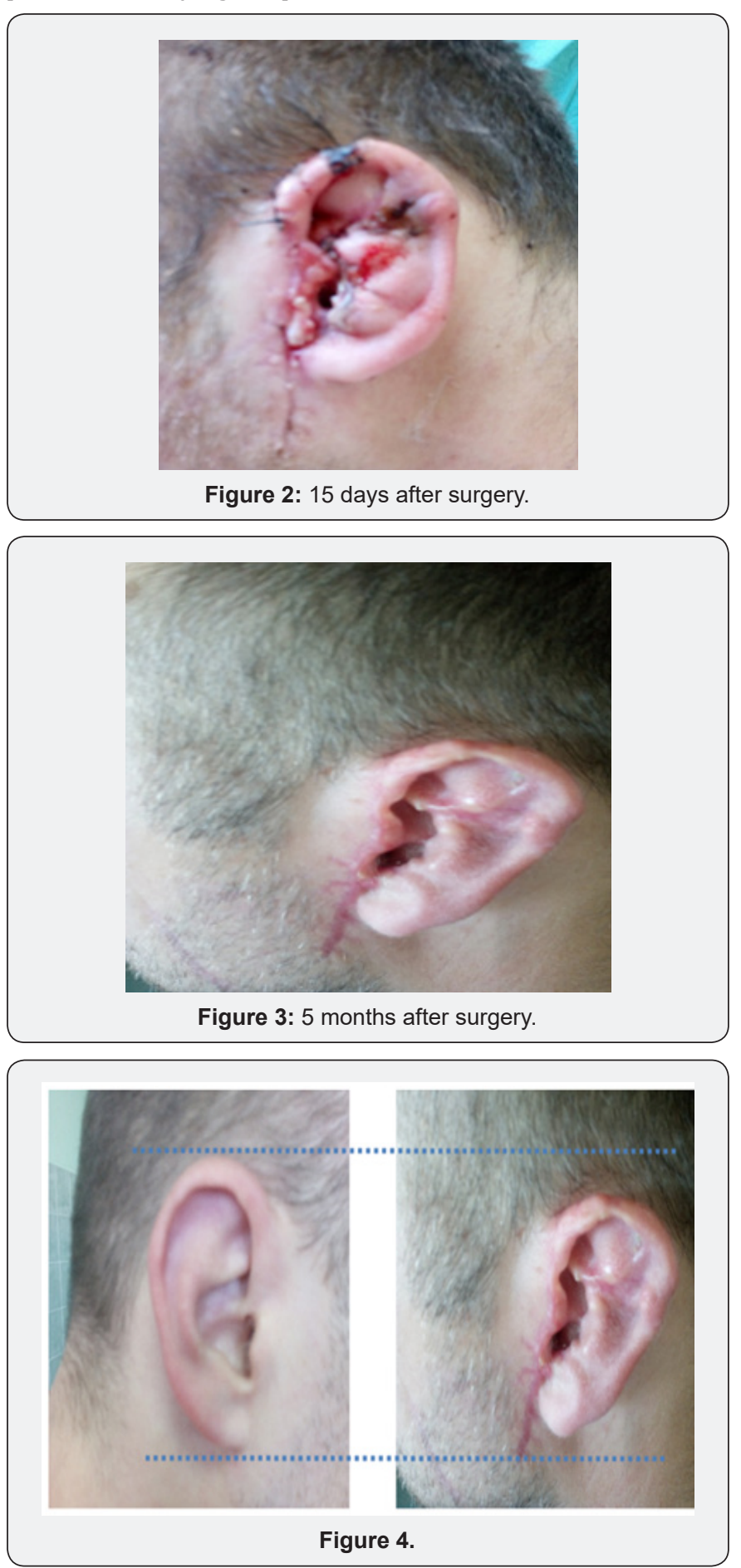

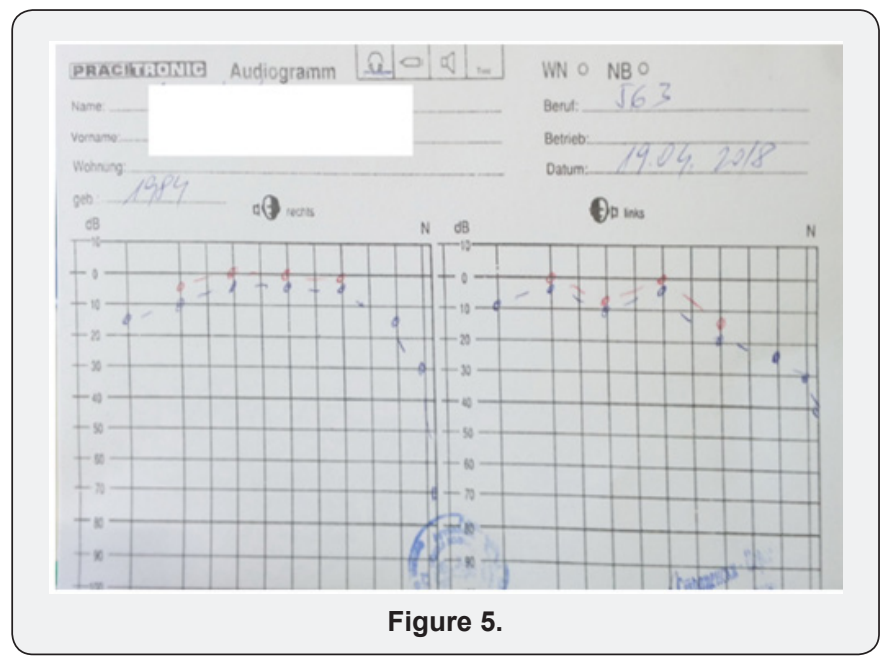

\section{Discussion}

After injuries and reconstructions like this , many complications could bee seen. Haematoma,an inflamation of the skin and cartilage - which could result in the deformations of the auricle,postoperative scar contracture and sstenosis of the external auditory canal. Psychological impact of auricular deformity is also very important consequence- because injury of the ear which demolishes normal architecture of the auricle can also have result in reduced self-confidence-because auricle is a decorateve structure [3].

\section{Conclusion}

The mechanism of the injury is very important factor and influences the treatment directly. Crush injuries are unlikely to be treated by simple reattachment or microsurgical anastomosis. In this case, secondary reconstruction with rib cartilage is probably preffered technique. However, due to other wounds of this patient, I tried to obtain an appropriate cosmetis result of the auricle in order to allow future ear reconstruction if neccessary.

\section{References}

1. Davison S (2017) Ear reconstruction and Salvage Procedures Treatment\&Management.

2. Kyrmizakis DE, Karatzanis AD, Bourolias CA, Hadjiioannou JK, Valerie's GA (2006) No microsurgical reconstruction of the auricle after traumatic amputation due to human bite. Head Face Med 2: 45.

3. Avelar JM, de Rezende Paolielo H (2013) Complications During and After Ear Reconstruction. In: Ear Reconstruction. Springer, Berlin, Heidelberg. 
(C) (i) Commons Attribution 4.0 License

(C) BY DO: 10.19080/GJO.2018.18.555982
Your next submission with Juniper Publishers will reach you the below assets

- Quality Editorial service

- Swift Peer Review

- Reprints availability

- E-prints Service

- Manuscript Podcast for convenient understanding

- Global attainment for your research

- Manuscript accessibility in different formats

( Pdf, E-pub, Full Text, Audio)

- Unceasing customer service

Track the below URL for one-step submission https://juniperpublishers.com/online-submission.php 